\title{
The Public/Private Partnership for Urban Regeneration in the USA
}

\author{
Tiziana Meduri ${ }^{1}$ a \\ ${ }^{1}$ Mediterranea University of Reggio Calabria - PAU - Department of Heritage, Architecture, Urban \\ Planning, Via Salita Melissari - 89124, Reggio di Calabria, Italy \\ atiziana.meduri@unirc.it
}

Keywords: Public/Private Partnership, Urban Regeneration, Community, No Profit.

\begin{abstract}
The paper examines the cooperation consists of the public/private partnership in the American environment, starting from the definition of the same, as experience shows partnership to represent the local government an alternative way to pursue growth and improvement in respect of sustainable development. In this context also shows the need for local government to work with business and the community to promote the territory's competitiveness, and wellness of local residents. The case of San Diego, California, shows how virtuous interaction and collaborative subjects (private, public, non-profit) has led to the economic and social development of different neighborhoods.
\end{abstract}

\section{Introduction}

The public-private partnership is a cooperation which is funded and operated through a partnership of government and one or more private sector companies. both parties, the government and local authorities on the one hand and the private sector on the other hand, realize joint projects with reciprocal benefits, taking advantage of their potential to achieve both economic and social objectives. The attainable advantages concern both cooperation partners, but in particular they concern members of the community, who are the ultimate recipients of services. In the American context it is clear that this model of cooperation operate, in most cases, to initiate processes of urban regeneration, thanks to the many government funding that can stimulate the participation of private individuals. The obtained results show the possibility of partnerships to define the territory in view of the economic sustainability of the interventions.

\section{The concept of public-private partnership}

The public/private partnership is a model of cooperation very popular in the U.S. for urban development especially since 1950 with the opening of the Renovated Urban Programme. The PPP can be considered a form of decisive action in the face of demographic changes and the cut in funding under the consideration that the government only with the support of the private sector could aim at solving social and economic problems related to the restructuring of the city. We have numerous definitions about the PPP. The Community Economic Development (CED) defines the public/private partnership as a cooperation between individuals and organizations in the public and private sectors for mutual benefit. This cooperation has two dimensions:

- a political dimension, in which they articulate the goals of the community;

- an operational dimension, in which these goals are pursued.

The cooperation's objective is to interact these two dimensions so that they are carried out not only benefits the community but also those of the partners constituting the partnership [1]. National Council for Urban Economic Development (CUED) cooperation Public/Private Urban Development involves the sharing of resources, expertise and coordination of activities. It is a negotiated deal in which they shared the risks, benefits and profits, in other words, that defines a multi-faceted process designed to gaps in the local investments, such as unavailability of capital, higher taxes and the weakness of potential demand for the project [2].

Another distinction Development Partnership identifies three types:

1. Partnership indirect, provide loans, tax incentives and public subsidies to private; 
2. Partnership aimed, in which the government plays a subordinate role as a partner and can be formalized in the BID (Business Improvement District)

3. Joint ventures, where the local government can have position stock certificate.

The spread of the PPP in American cities is mainly due to the effective organizational capacity of the private sector, in which a key role is played by the non-profit associations, numerous incentives for cooperation connected to the autonomy of local governments in the federal system of USA. This independence allows the negotiation between sectors and deal-making.

Of course, the incentives vary according to the different legal structures of the different systems of government. As well as national circumstances and institutional differences have an impact on the forms of PPP. We have in principle a "partnership model of European Strong State" and a "market-oriented United States" [3].

The partnership provides a means to achieve greater efficiency in the use of public and private resources through negotiations and contractual agreements. In fact, city governments have a lot of power to be able to use for the purpose of territorial development: provision of financial powers of taxation, power to expropriate authority to and Tax-Increment Financing (TIF). We can differentiate between financial incentives, non-financial and administrative incentives. In particular, the financial incentives are used in order to stimulate investment and concentrate them in targeted areas; administrative incentives can be used by local authorities when a project promotes public goals. The local government provides development assistance through the acquisition of land. A fundamental change in the role of local government in urban development took place with the commitment of the public sector in direct debt and equity financing. Traditionally, equity financing "represents an investment of an owner or part owner of a company," while the debt financing "refers to a loan made by a bank to provide capital to an entrepreneur" [4]. With the system of direct debt, a public body makes or guarantees loans or subsidies. In contrast the detention of even partial ownership of a company or a development project becomes more risky for local governments, since the recovery of investment by the municipality depends on the success of the company or project. In addition, the loan guarantees are also a means to reduce the risk of get funding from private lenders. Debt financing is very common, if it can distinguish three types: direct loans, loan guarantees, bond financing income. The loan guarantee is a means to lower the cost of credit. In this situation, the local government provides to a private creditor that a specific portion of the loan will be repaid in the event of default. Therefore, it reduces the risk to the private lender. The bonds sold by municipalities are tax exempt from federal taxation, for which the cost of borrowing through tax-exempt bonds are lower for the town than it is for private lenders.

The investment partnerships are much more prevalent and visible of social partnerships in the United States, these are geared to the economic development of Downtown and the Center

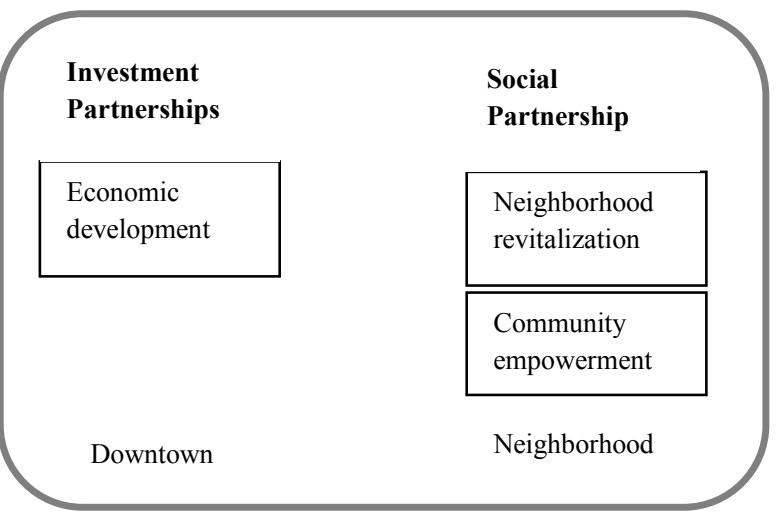

Fig. 1 Investment and Social Partnership Bussiness District (CBD), while social partnerships, in contrast, are to support the development of the district, municipal services, housing and jobs, (Fig.1). These partnerships are more "inclusive" and aimed at a wider participation and distribution of social and economic development. The program of the Federal Empowerment Zones and Enterprise Communities (EZ / EC) can be considered an appropriate example of such "new" partnership approaches [5,6], in the United States. In this context, a more defined role since 1980 has been played by non-profit organizations. An example of such associations working for the betterment of the neighborhood are the Community Development Corporations (CDC). 


\section{The main models of urban management in the U.S.}

In this category are:

Business Improvement District (BID), examples of public-private partnership, in which there emerges the leading role of municipal governments to promote community-based solutions to the problems of the community [7,8], and are among the policies at the international level to improve the economic vitality of urban communities, promote the revitalization of urban areas and promote an innovative approach to the provision of public services $[9,10]$. A BID is a private organization in which small companies integrate public services and programs, in addition to what the municipality can provide to keep neighborhoods clean, improve operations, transportation, and aesthetics of public places. It can be initiated by a non-profit organization, to public-private partnerships or by a public body - not profit. Depending on state law, the BID can be financed in a variety of ways, including through a tax assessment, mill levy or tax increment financing (TIF) on the property tax, and therefore managed by non-profit agency. The innovative factor introduced is based on the flexible form of urban governance offering, which is a partnership designed

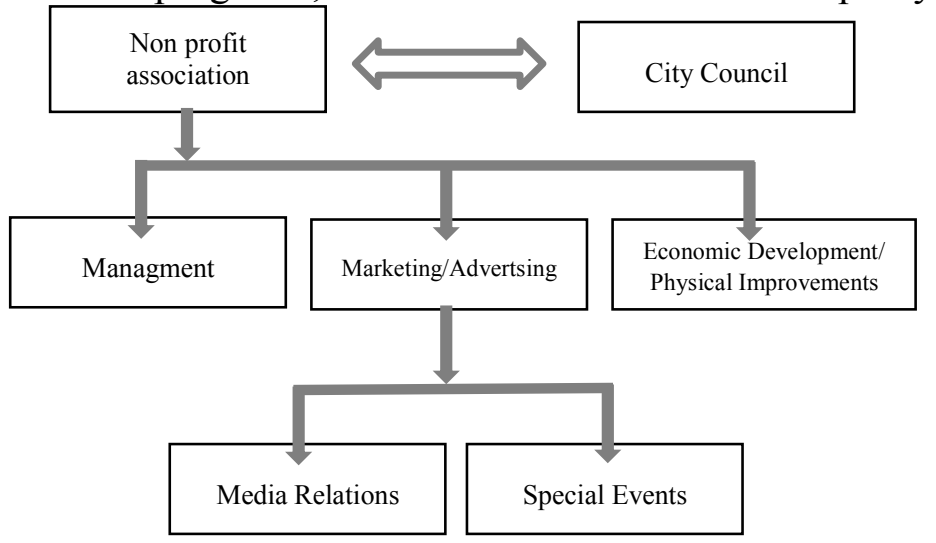

Fig. 2 The braided relationship between the public and private interests in a BID to bring together public, private and civic organizations to achieve the overall objectives of the Community [11]. In California, the establishment of the BID is authorized by two state laws: one that allows for the creation of commercial districts based on a special assessment districts for the property. In both cases, the majority of business owners or commercial property owners in a given area may decide to acquire special benefits and pay independently of the benefits obtained. The organization is required to provide financial reports on the use of funds for evaluation. The municipality is also authorized to inspect and review the financial condition of a BID, (Fig.2). In this way the city assists the BID with the review, so that the special assessment is used according to the budget. The city then assumes a certain role in the BID program and the relationship that you create with the companies can be described as a formal public-private partnership with a low involvement of the public sector.

The Community Development Corporations (CDC) are non-profit organizations that aim at social and economic development of the communities in difficulty and low income. Their action has become more poignant since 1980, showing mainly active in providing financial assistance for the construction of low cost housing in projects to commercial and industrial development, and the promotion of small businesses in their communities. They provide equity capital, loans and technical assistance to businesses. This type of authority are characterized by an Internal Revenue Service (IRS) 501 (c) (3) tax-exempt status for nonprofit, which allows them to avoid some federal taxes [12] and to better carry out their purposes social. The areas of intervention are generally urban neighborhoods or only portions that show a weak social and economic structure, characterized by disinvestment and high rates of unemployment, which is also the reason why for-profit organizations generally avoid these areas. The principle that is the basis of their actions is that neighborhoods can be effective in generating economic growth and employment thanks to cohesion and mutual support that can be found within the same community.

Differently from private entrepreneurs and government institutions, the CDC are able to respond quickly to opportunities for development, in addition to the achievement of their strategic goals becomes to maintain strong ties with the community, involving residents in their governance and development, to ensure that development projects meet the needs of the community. Demonstrating the involvement of citizens in their activities, CDC can also advance a valid claim on the financial, technical and political. But the CDC are designed to do more: their goal is to catalyze a chain 
reaction of improvement at the neighborhood level. CDC has a fundamental role in building the wealth of the community for several reasons: it increases the real estate capital through the development of residential and commercial properties, ranging from affordable housing to shopping centers and even businesses; allows direct participation in the process decision given that at least one third of the board of a CDC is typically made up of community residents, promotes accountability for the actions of residents, working with them to improve the conditions of the community.

There is also the approach Main Street, which is a tool of economic development based on conservation that allows the community to revitalize the downtown and the business district using local resources, historical, cultural and architectural as well as the firms. This was launched in 1977 by the National Trust of Historic Preservation. The local non-profit organization operates through a partnership between local businesses, property owners, residents and members of other local associations, and is structured into several committees, combining different activities in four themes that intersect:

-Organization, to build consensus and partnerships between stakeholders;

-Promoting and marketing, to create a positive image that allows you to rediscover its identity to the community and improve the confidence of consumers and investors in the commercial district, through special events and retail promotions;

-Design, to create an attractive environment by directing attention to all its physical elements: public and private buildings, storefronts, signs, public spaces, car parks, street furniture, public art, landscaping, merchandising, window displays, and promotional material. This aspect also includes the dissemination of good maintenance practices in the commercial district, enhancing the physical appearance of the district through the rehabilitation of historic buildings and by raising awareness of entrepreneurs about the quality of the design and long-term planning.

-Economic restructuring, to strengthen existing local activities, to diversify its economic offer and attract new investment [13].

The key aspect of the approach Main Street is the need for a full time manager and a strong public-private partnership, as well as the knowledge that a strong organization, effective promotions, a commitment to design quality and economic diversification are necessary to achieve historic preservation [14]. The approach is based on the Main Street historic preservation as a tool to exploit the abundance of old buildings and underutilized and trade as a lever for the regeneration of urban areas, the restoration of urban centers as centers of community life and social business. It can also be considered as a "platform of government," where communities, public bodies and the private sector are working together on a shared vision for the regeneration of a specific area [15]. The funding is usually related to revenue from local businesses, residents, property owners and visitors, but also from fundraising projects and corporate donations. Sometimes they receive from the city government, technical assistance, training and financial support in the form of grants. In this scenario shows the evolution of the role of the public sector, from that of a provider of resources to a resource broker, and the active and direct involvement of local communities in a context of regeneration flexible in the sense that every Main Street could be different due to the different needs, activities, and local opportunities [16].

In situations of partnership is evident the significant role played by the community, because it interacts fully in the process of revitalization of neighborhoods, in the mechanisms of development and planning of the same. The participation of the community becomes a strong point for the success of the intervention projects because the constituents the same familiar with the opportunities and problems of their neighborhoods [17].

\section{The example of the city of San Diego in California}

The city of San Diego is illustrative to describe the growing importance of public/private partnerships for urban regeneration to sustainable development of the territory.

The actions of redevelopment in the city of San Diego are conducted Redevelopment Agency of the City. In addition to these two companies are engaged in developing autonomous regeneration in 
well-defined geographical areas: the City Centre Development Corporation (CCDC), which manages the redevelopment in downtown San Diego and the South East Economic Development Corporation (SEDC), established in 1981 to carry out redevelopment activities in the south-east of San Diego. Both development companies have been established to facilitate public-private partnerships in development projects and have a wide range of powers including that of ensuring public financing, negotiating agreements with developers, and the review of development proposals to ensure that they meet the design criteria and other public objectives [18].

As part of the actions to urban regeneration an important instrument of government is the BID of the county of San Diego, which is used to revitalize older commercial districts throughout the city, for the creation of new jobs, attracting new businesses, strengthen communities made up of small businesses and to provide traders with the business areas the necessary tools to develop marketing campaigns. twenty-five percent of small business owners of the city lies within the boundaries of one of the City BID. Each commercial district, made up of hundreds of companies, is in turn represented by a Main street organization incorporated as a management company non-profit. Under contract with the city, these management companies are non-profit organization responsible for the management of programs and activities to promote and revitalize historic commercial districts of the original San Diego. In 1993 he established the San Diego Business Improvement District Council, a non-profit organization that receives annual funding from the City of San Diego's Small Business Enhancement Program whose members are associations of the 19 BID in the area.

The economic impact of BIDs in the San Diego region is as follows:

- With approximately 12,000 dealers and $\$ 12.5$ million in annual revenues, business improvement districts are the largest program of self-sufficient small businesses in San Diego.

- 2008 to 2010, business improvement districts in San Diego have created a regional economic impact of $\$ 47.4$ million.

- Each year, the BID spending supports about 233 jobs.

- Most of the members of the BID receive a return equal to 5 times the investment for their annual assessments [19].

\section{Conclusions}

What has been argued so far is a cognitive analysis of a reality, like that of St. Diego, what is the best practice, which exploits the cooperation between public and private organizations for socioeconomic development, it is the fundamental starting point for the identification of strategic actions adopt in the future context of Reggio Calabria's metropolitan city, especially in areas lagging behind, to revitalize specific territorial contexts that today despite having the right resources and potential, in conditions of social and economic degradation, those who have given in the past years, the continuous abandonment of the territory. What emerges is the important role that community, both as a recipient of any intervention, either as an active, even from the economic point of view, the possible actions to be taken to the area.

\section{Acknowledgements}

The 7th European Research Framework - Marie Curie IRSES actions granted the CLUDs project.

\section{References}

[1] Committee for Economic Development (CED) (1982): Public-private partnership. An Opportunity for Urban Communities. Washington, D.C.

[2] CUED (1978): Coordinated Urban Economic Development

[3] P. Newman, G. Verpraet: The impacts of partnership on urban governance: conclusions from recent European research. Regional Studies, Vol.33, No.5, (1999), p.487 
[4] Committee for Economic Development (CED) (1978:296)

[5] D. Haider: in: P. Davis, Public-Private Partnerships: Improving Urban Life, (1986)

[6] F. Calabrò, L. Della Spina: The public-private partnerships in buildings regeneration: a model appraisal of the benefits and for land value capture. In: 5nd KKU International Engineering Conference 2014 (KKU-IENC 2014). ADVANCED MATERIALS RESEARCH, Vols. 931932 (2014) pp 555-559 (C) (2014) Trans Tech Publications, Switzerland doi:10.4028/www.scientific.net/AMR.931-932.555, (2014)

[7] S. A. Grossman: The Case of Business Improvement Districts. Special District Public-Private Cooperation in Community Revitalization, in Public Performance \& Management Review, 32 (2), (2008), pp. 290-308

[8] J. Mitchell, Business Improvement Districts and Innovative Service Delivery, The PricewaterhouseCoopers Endowment for the Business of Government, New York (1999)

[9] J. Mac Donald, R. Stokes, R. Bluthenthal: The Role of Community Context in Business District Revitalization Strategies. Business Improvement Districts in Los Angeles, in Public Performance \& Management Review, 33(3), (2010), pp. 436-458

[10] J. Mitchell: Business Improvement Districts and the "New" Revitalization of Downtown, in Economic Development Quarterly, 15, (2001), pp. 115-123

[11] S. A. Grossman: The Case of Business Improvement Districts. Special District Public-Private Cooperation in Community Revitalization, in Public Performance \& Management Review, 32 (2), (2008), pp. 290-308

[12] R. Stoecker: The CDC Model Of Urban Redevelopment: A Critique and an Alternative. Journal of urban affairs, Volume 19, Number 1, (1997), pp. 1-22

[13] Information on: http://www.preservationnation.org/main-street/about-main-street/theapproach/

[14] K. A. Robertson: The main street approach to downtown development: an examination of the four-point program, Journal of Architectural and Planning Research, Locke Science Publishing Company, Inc. Chicago, IL, USA

[15] A. L. Dono, L. S. Glisson: Revitalizing main street: a practitioner's guide to comprehensive commercial district revitalization, Washington, DC: Main Street, National Trust for Historic Preservation/National Trust Main Street Center (2009)

[16] S. G. Dane: Main Street success stories, National Main Street Center, National Trust for Historic Preservation (1997)

[17] F. Calabrò, L. Della Spina: The cultural and environmental resources for sustainable development of rural areas in economically disadvantaged contexts. Economic-appraisals issues of a model of management for the valorisation of public assets. In 3rd International Conference on Energy, Environment and Sustainable Development (ICEESD 2013). Advanced Materials Research Vols. 869-870 (2014) pp 43-48 (C) (2014) Trans Tech Publications, Switzerland doi:10.4028/www.scientific.net/AMR.869-870.43, (2014)

[18] G. M. Trimble, S. L. Rogel: Codevelopment Rebuilds Downtown Excitement, In: ULI (1983)

[19] V. Vasquez: The economic impact of business improvement districts (bids) in San Diego, National University System Institute for policy research (2012) 